\section{Structural Derivatization of Clusianone and In Vitro Cytotoxicity Evaluation Targeting Respiratory Carcinoma Cells}

\section{Sree Vaneesa Nagalingam, Kok Wai-Ling, Khoo Teng-Jin}

Centre for Natural and Medicinal Product Research, School of Pharmacy, Faculty of Science, University of Nottingham Malaysia Campus, Semenyih, Selangor, Malaysia

\section{Abstract \\ $\nabla$}

Clusianone (1) was isolated from Garcinia parvifolia and structurally modified using semisynthetic methods to obtain compounds 2-4. The structural derivatization included methylation (2), hydrogenation (3), and the addition of a methylamine group [(4) to (1)]. Cytotoxic effects of these compounds were assessed on MRC5 fibroblasts, A549 lung adenocarcinoma, HK1 squamous nasopharynx carcinoma, and NP69 normal nasopharyngeal epithelial cell lines. Clusianone (1) showed cytotoxic activity against A549 cells with an $\mathrm{IC}_{50}$ value of $3.06 \mu \mathrm{M}$. Compound (4) showed cytotoxic activities against both $\mathrm{A} 549$ and $\mathrm{HK} 1$ cells with $\mathrm{IC}_{50}$ values of $4.09 \mu \mathrm{M}$ and $3.43 \mu \mathrm{M}$, respectively. The results of the cytotoxicity assay provide a correlation on the structure activity relationship of clusianone against HK1 and A549 cells, which can be further investigated as a potential antiproliferative compound.

\section{Key words}

Garcinia parvifolia $\cdot$ Clusiaceae $\cdot$ clusianone analogues $\cdot$ semisynthetic methods $\cdot$ cytotoxic activity

Supporting information available online at http://www.thieme-connect.de/products

Natural clusianone belongs to compounds classified as type B polyprenylated polycyclic acylphloroglucines (PPAPs) that are found in plants of the Clusiaceae (Guttiferae) family [1,2]. To date, natural clusianone has been found in various parts of the targeted Clusiaceae plants, including fruits [3], flowers [4,5], leaves [6], roots [7], stems, and bark [8,9]. Naturally occurring 1 has shown potential anticancer activity [9] and further investigations of clusianone-treated HepG2 hepatocarcinoma cells revealed cytotoxic effects by mitochondrial impairment [10]. In the last decade, clusianone (1) has gained substantial interest from the synthetic community leading to a breakthrough in total synthesis of this compound [11-14]. Synthetic clusianone was tested for cytotoxicity in several cancer cell lines: HeLa (cervix carcinoma), MIAPaCa-2 (pancreatic carcinoma), and MCF7 (breast adenocarcinoma). The IC $\mathrm{I}_{50}$ values ranged from $3.0 \mu \mathrm{M}$ to $8.3 \mu \mathrm{M}$ for the three cancer cell lines $[15,16]$.

In our studies, we extracted clusianone using a previously published method [6]. The isolation and abundance of clusianone from the leaves of Garcinia parvifolia (Miq.) Miq. has made chemical modifications readily attainable as compared to clusianone isolated from the dried stem bark of Garcinia assigu [9] and the roots of Hypericum hypericoides (L.) Crantz [7]. X-ray crystallography was identical in previous reports, and a detailed comparison of our and previously reported NMR data [8] was established.
This method provided a quantity of over $0.5 \mathrm{~g}$ ( $0.05 \%$ yield) of 1 to be used as starting material for synthesizing sufficient quantities of clusianone derivatives (2-4). All products were purified via column chromatography. The products 1-4 exhibited the predicted fragmentation and mass $m / z$ when analyzed by ESI-MS ( Fig. 1). In addition, further characterizations of 1-4 were conducted utilizing ${ }^{1} \mathrm{HNMR}$ and ${ }^{13} \mathrm{CNMR}$ spectroscopy to characterize both tautomers (a/b) present. Data on clusianone and analogues are available as Supporting Information. Furthermore, clusianone derivatives (2-4) were produced in less than two reactions steps, with yields over $75 \%$ ( $\bullet$ Fig. 2).

A bioassay involving the (MTT) tetrazolium dye reduction assay revealed that the cytotoxic effects of all four compounds (1-4) against normal (MRC5 \& NP69) and carcinoma (A549 \& HK1) respiratory cells lines were profound. The $\mathrm{IC}_{50}$ values after $48 \mathrm{~h}$ were averaged from three sets of experiments ( Table 1 ). The $\mathrm{IC}_{50}$ values were determined from the resulting dose response plot by using the interpolation methods in GraphPad Prism 6. Cytotoxicity screening tests were also performed against normal cell lines to validate the compound inhibitory activity in cancer cells without significantly affecting the viability of normal cells. Based on these results, several findings can be summarized: The methoxylation of $\mathrm{OH}$ has decreased the cytotoxic effects of 2 on both cancer and normal cells by 30 -fold. Compound $\mathbf{2}$ is also less toxic to normal cells in terms of concentration, which is lethal to $50 \%$ of the cells. Upon hydrogenation, the tetraprenylated group of 2 leads to a more lipophilic domain of this compound, which has indeed decreased the cytotoxic effect of 3 by 20 -fold. The cytotoxicity result of compound 4 is rather significant since the $\mathrm{IC}_{50}$ value is in the range of 3.0 to $5.0 \mu \mathrm{M}$. Interestingly, compound 4 suppressed the growth rate of MRC5 and NP69 at concentrations above $10.0 \mu \mathrm{M}$. Compound 4 showed significant cytotoxic activities against both $\mathrm{A} 549$ and $\mathrm{HK} 1$ cells with $\mathrm{IC}_{50}$ values of $4.09 \mu \mathrm{M}$ and $3.43 \mu \mathrm{M}$, respectively. Apart from this, clusianone (1) showed a significant $\mathrm{IC}_{50}$ value of $3.06 \mu \mathrm{M}$ against $\mathrm{A} 549$ cells and thus affects less MRC5 cells. Cytotoxicity results prevail that a hydroxyl group on clusianone is crucial in preventing the cell division progression to occur. Similarly, compound 4 possessing both hydroxyl and amine is postulated to exert a greater interaction with carcinoma cells since 4 suppressed carcinoma cell growth better than $\mathbf{1}$. This indicates that compounds $\mathbf{1}$ and $\mathbf{4}$ both exhibit antiproliferative characteristics. The antimicrotubule drug docetaxol was used as a control since type B PPAP compounds have been demonstrated to exhibit an inhibitory activity of the tubulin assembly of carcinoma cells [17]. In conclusion, 1 and $\mathbf{4}$ have potential for development as anticancer candidates, and future works to study their modes of action as antimictrotubule agents should be emphasized.

\section{Material and Methods $\nabla$}

\section{Isolation and optimization of clusianone}

Leaves of G. parvifolia (University of Nottingham Malaysia Campus 45) were collected from trees in a reserved forest in Sungai Congkak, Selangor. The plant authenticity was verified and a voucher specimen (herbarium number PID 271210-13) was deposited at the School of Pharmacy of the University of Nottingham Malaysia Campus and Forest Research Institute Malaysia (FRIM). Dried and powdered G. parvifolia leaves (1000 g) were extracted by maceration. A total of $80 \mathrm{~g}$ of hexane extract was obtained from the $1000 \mathrm{~g}$ of powdered leaves macerated. Successive 


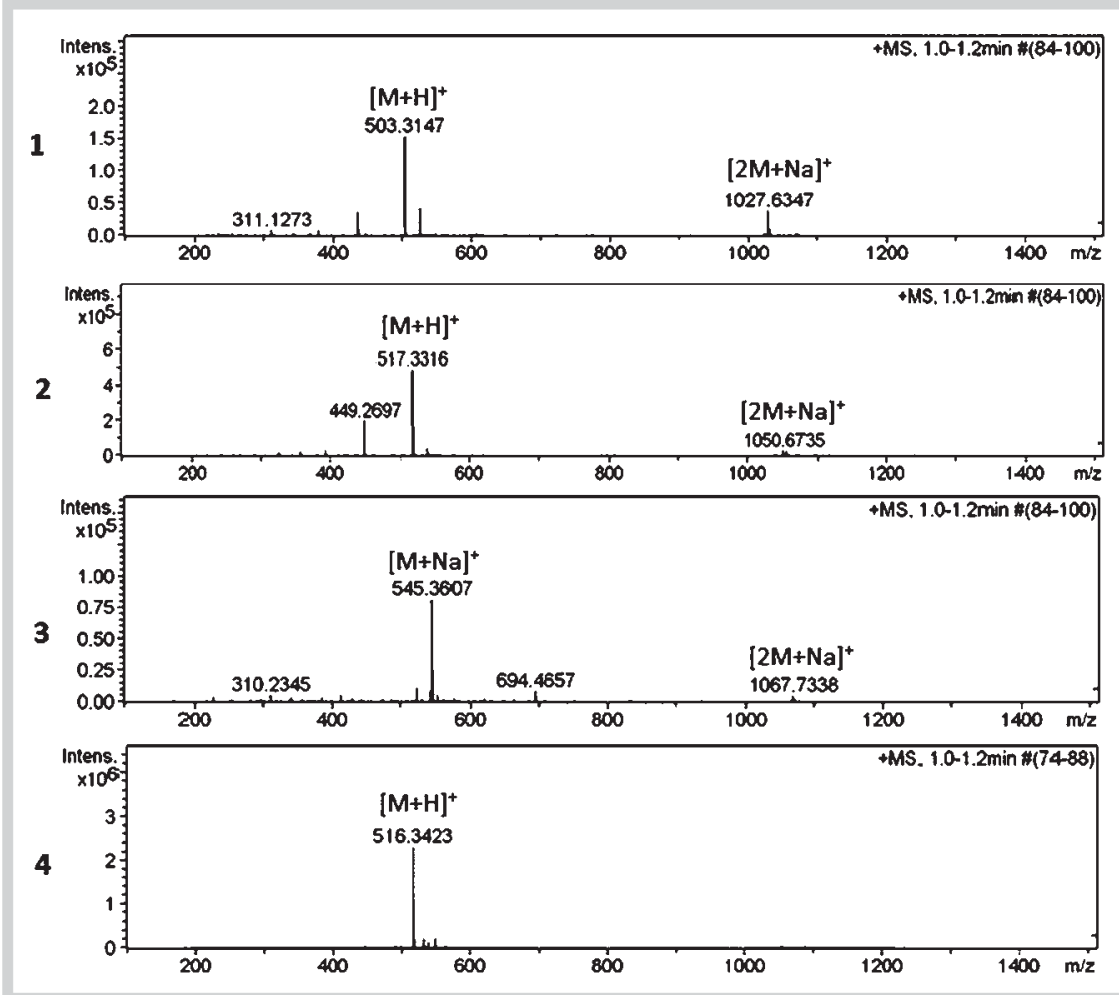

Fig. 1 ESI-MS analysis of clusianone and its derivatives (1-4) demonstrating the parent mass of the compounds and dimer formations with adducts $\mathrm{H}^{+}$ and $\mathrm{Na}^{+}$.

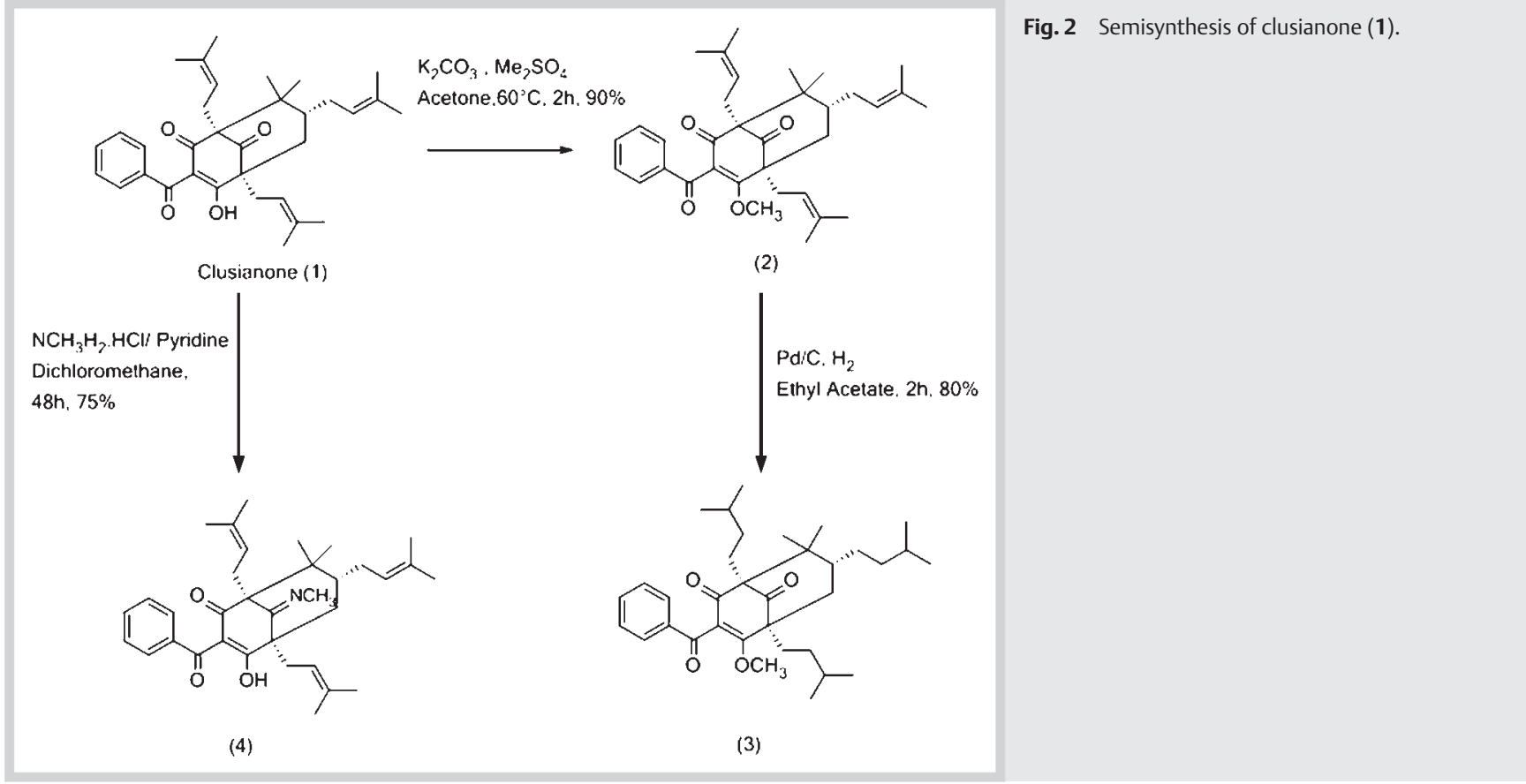

column chromatography, including chlorophyll removal steps, was carried out as previously reported in a larger scale to obtain clusianone (1) [6].

\section{Preparation of clusianone derivatives}

Three clusianone (1) derivatives [methylated (2), hydrogenated (3), and amine added (4)] were synthesized on a 10 to $100 \mathrm{mg}$ scale and purified using column chromatography. All derivatives were synthesized from clusianone except for $\mathbf{3}$, which was syn- thesized from 2 intermediately. Detailed synthesis steps and ESI-MS, ${ }^{1} \mathrm{H}$ NMR, and ${ }^{13} \mathrm{C}$ NMR characterizations of the four compounds are available as Supporting Information.

\section{Compounds}

Clusianone $\left(\mathrm{C}_{33} \mathrm{H}_{42} \mathrm{O}_{4}\right)$ : Yellow crystals; m.p. 90-92 ${ }^{\circ} \mathrm{C}$; ESI-MS m/ $z,[\mathrm{M}+\mathrm{H}]^{+}: 503.3147$ calcd. for 503.3167 (rel. int. \%) = $503(100)$, 435 (23), 379 (4.5), 343 (1.9), 311 (4.6), 235 (1.7). For ${ }^{1} \mathrm{H}$ NMR and ${ }^{13} \mathrm{C}$ NMR of $\mathbf{1}(\mathrm{a} / \mathrm{b})$, see Tables $\mathbf{S 1}$ and $\mathbf{S 2}$, Supporting Information. 


\begin{tabular}{lccrr} 
Compound & MRC5 & A549 & NP69 & HK1 \\
\hline Clusianone (1) & $4.16 \pm 0.85$ & $3.06 \pm 1.00$ & $3.66 \pm 0.94$ & $5.35 \pm 0.91$ \\
$\mathbf{2}$ & $120.38 \pm 2.98$ & $86.70 \pm 1.60$ & $101.02 \pm 2.92$ & $62.70 \pm 2.52$ \\
$\mathbf{3}$ & $47.15 \pm 2.05$ & $57.70 \pm 1.93$ & $68.80 \pm 2.01$ & $65.55 \pm 1.74$ \\
$\mathbf{4}$ & $10.20 \pm 0.82$ & $4.09 \pm 0.61$ & $10.02 \pm 0.52$ & $3.43 \pm 0.57$ \\
Docetaxol $^{\mathrm{a}}$ & 0.006 & 0.006 & 0.006 & 0.006
\end{tabular}

Table 1 Cytotoxicity $\mathrm{IC}_{50} \pm \mathrm{SD}$ $(\mu \mathrm{M})$ of clusianone and its derivatives against MRC5, A549, HK1, and NP69 cells.

aDocetaxol control; MRC5 (lung fibroblast) [19], A549 (lung adenocarcinoma) [20], NP69 (immortalized nasopharyngeal epithelial cell)

[21], HK1 (squamous carcinoma of the nasopharynx) [22]

Compound $2\left(\mathrm{C}_{34} \mathrm{H}_{44} \mathrm{O}_{4}\right)$ : White crystals; m.p. $108-110^{\circ} \mathrm{C}$; ESI-MS $m / z,[\mathrm{M}+\mathrm{H}]^{+}: 517.3316$ calcd. for 517.3318 (rel. int. \%) $=517$ (100), 449 (40.6), 393 (5.3), 357 (4.2), 325 (4.0). For ${ }^{1} \mathrm{H}$ NMR and ${ }^{13} \mathrm{C}$ NMR of $\mathbf{2}(\mathrm{a} / \mathrm{b})$, see Tables S3 and \$4, Supporting Information.

Compound $3\left(\mathrm{C}_{34} \mathrm{H}_{50} \mathrm{O}_{4}\right)$ : Brown wax; ESI-MS $m / z$, $[\mathrm{M}+\mathrm{Na}]^{+}$: 545.3607 calcd. for 545.3607 (rel. int. \%)= 545 (100), 523 (13.4), 429 (2.8), 413 (5.5), 385 (3.4), 341 (3.3), 310 (6.0), 226 (4.0). For ${ }^{1} \mathrm{H}$ NMR and ${ }^{13} \mathrm{C}$ NMR of $\mathbf{3}(\mathrm{a} / \mathrm{b})$, see Tables S5 and S6, Supporting Information.

Compound $4 \mathrm{C}_{34} \mathrm{H}_{45} \mathrm{NO}_{3}$ : Colorless wax; ESI-MS $m / z$, $[\mathrm{M}+\mathrm{H}]^{+}$: 516.3423 calcd. for 516.3478 (rel. int. \%)=517 (100), 498 (1.7), 490 (2.0), 448 (1.1). For ${ }^{1}$ H NMR and ${ }^{13}$ C NMR of 4 (a/b), see Table s7, Supporting Information.

\section{Cytotoxicity assay}

All stock cultures, except for the NP69 cultures, were grown in T25 flasks with Rosewell Park Memorial Institute medium (RPMI) containing 10\% fetal bovine serum (FBS). NP69 cultures were grown in keratinocyte-SFM together with a supplement of bovine pituitary extract (BFE) and human recombinant (EGF). Freshly trypsinized cells were seeded into 96-well plates at densities of 10000 cells in $100 \mu \mathrm{L}$ medium per well. After one day of culture, each of the wells was subjected to different concentrations of the compounds, from $0-200 \mu \mathrm{g} / \mathrm{mL}$. The compounds were dissolved in dimethyl sulfoxide (DMSO) and diluted further with RPMI medium for all cultures, except for NP69, which was diluted with keratinocyte-SFM that serves as a stock solution. The DMSO concentration used was not higher than $0.1 \%$. Different concentrations of the compounds (1-4) were prepared through a serial dilution of the stock solution. The plates were then incubated for $48 \mathrm{~h}$ to test their cytotoxicity levels. Docetaxol (Fresenius Kabi Oncology Ltd.), with a purity of 99\%, was used as a positive control. The docetaxol was dissolved in sodium chloride buffer. After $48 \mathrm{~h}$ of treatment, the MTT [3-(4,5-dimethylthiazol-2-yl)-2,5-diphenyltetrazolium bromide] assay was performed [18]. Absorbance readings were set at $540 \mathrm{~nm}$ using a microplate reader. The absorbance was further analyzed as described in the Supporting Information.

\section{Supporting information}

A detailed description of the semisynthesis process, spectral data of clusianone and its analogues, and absorbance data are available as Supporting Information.

\section{Acknowledgements}

$\nabla$

We would like to thank Dr. Alan Khoo Soo-Beng from the Institute of Medical Research and Prof. Tsao George Sai-Wah from the University of Hong Kong for providing the NP69 and HK1 cells. The authors would like to thank the Ministry of Higher Education (MOHE) for providing a grant for the study.

\section{Conflict of Interest}

$\nabla$

All authors declare no conflicts of interest.

\section{References}

1 Ciochina R, Grossman RB. Polycyclic polyprenylated acylphloroglucinols. Chem Rev 2006; 106: 3963-3986

2 Biber N, Möws K, Plietker B. The total synthesis of hyperpapuanone, hyperibone L, epi-clusianone and oblongifolin A. Nat Chem 2011; 3: 938942

3 Piccinelli AL, Cuesta-Rubio O, Chica MB, Mahmood N, Pagano B, Pavone $M$, Barone V, Rastrelli L. Structural revision of clusianone and 7-epi-clusianone and anti-HIV activity of polyisoprenylated benzophenones. Tetrahedron 2005; 61: 8206-8211

4 Porto AL, Machado SM, de Oliveira CM, Bittrich V, Amaral MC, Marsaioli AJ. Polyisoprenylated benzophenones from Clusia floral resins. Phytochemistry 2000; 55: 755-768

5 Da Silva MCA, Heringer AP, Figueiredo MR, de Paiva SR. Separation of clusianone from Clusia fluminensis Planch. and Triana (Clusiaceae) by high speed counter current chromatography (HSCCC). J Liq Chromatogr Relat Technol 2012; 35: 2313-2321

6 Nagalingam SV, Ching WPJ, Break MK, Tahir MIM, Khoo TJ. A P2 $2_{1} 2_{1} 2_{1}$ polymorph of (+)-clusianone. Acta Crystallogr Sect E Struct Rep Online 2013; 69: 1799-1800

7 Christian OE, McLean S, Reynolds WF, Jacobs H. Prenylated benzophenones from Hypericum hypericoides. Nat Prod Commun 2008; 3 : $1781-1786$

8 McCandlish LE, Hanson JC, Stout GH. The structures of two derivatives of bicyclo[3.3.1]nonane-2, 4, 9-trione. A natural product: clusianone, $\mathrm{C}_{33} \mathrm{H}_{42} \mathrm{O}_{4}$, and trimethylated catechinic acid, $\mathrm{C}_{18} \mathrm{H}_{20} \mathrm{O}_{6}$. Acta Crystallogr B 1976; 32: 1793-1801

9 Ito C, Itoigawa M, Miyamoto Y, Onoda S, Rao KS, Mukainaka T, Tokuda H, Nishino H, Furukawa H. Polyprenylated benzophenones from Garcinia assigu and their potential cancer chemopreventive activities. J Nat Prod 2003; 66: 206-209

10 Reis FH, Pardo-Andreu GL, Nuñez-Figueredo Y, Cuesta-Rubio O, MarínPrida J, Uyemura SA, Curti C, Alberici LC. Clusianone, a naturally occurring nemorosone regioisomer, uncouples rat liver mitochondria and induces HepG2 cell death. Chem Biol Interact 2014; 212: 20-29

11 Rodeschini V, Ahmad NM, Simpkins NS. Synthesis of ( \pm )-clusianone: high-yielding bridgehead and diketone substitutions by regioselective lithiation of enol ether derivatives of bicyclo[3.3.1]nonane-2, 4, 9-triones. Org Lett 2006; 8: 5283-5285

12 Qi J, Porco JA jr. Rapid access to polyprenylated phloroglucinols via alkylative dearomatization-annulation: total synthesis of ( \pm )-clusianone (1). J Am Chem Soc 2007; 129: 12682-12683

13 Nuhant P, David M, Pouplin T, Delpech B, Marazano C. Alpha,alpha'-annulation of 2, 6-prenyl-substituted cyclohexanone derivatives with malonyl chloride: application to a short synthesis of $( \pm)$-clusianone. Formation and rearrangement of a biogenetic-like intermediate. Org Lett 2007; 9: 14200-14201

14 Garnsey MR, Lim D, Yost JM, Coltart DM. Development of a strategy for the asymmetric synthesis of polycyclic polyprenylated acylphloroglucinols via $\mathrm{N}$-amino cyclic carbamate hydrazones: application to the total synthesis of (+)-clusianone. Org Lett 2010; 12: 5234-5237

15 Simpkins NS, Holtrup F, Rodeschini V, Taylor JD, Wolf R. Comparison of the cytotoxic effects of enantiopure PPAPs, including nemorosone and clusianone. Bioorg Med Chem Lett 2012; 22: 6144-6147

16 Simpkins NS. Adventures in bridgehead substitution chemistry: synthesis of polycyclic polyprenylated acylphloroglucinols (PPAPs). Chem Commun (Camb) 2013; 49: 1042-1051 
17 Roux D, Hadi HA, Thoret S, Guénard D, Thoison O, Païs M, Sévenet T. Structure-activity relationship of polyisoprenyl benzophenones from Garcinia pyrifera on the tubulin/microtubule system. J Nat Prod 2000; 63: 1070-1076

18 Mosmann T. Rapid colorimetric assay for cellular growth and survival: application to proliferation and cytotoxicity assays. J Immunol Methods 1983; 65: 55-63

19 Jacobs JP, Jones CM, Baille JP. Characteristic of human diploid cell designated MRC-5. Nature 1970; 227: 168-170

20 Giard DJ, Aaronson SA, Todaro GJ, Arnstein P, Kersey JH, Parks WP. In vitro cultivation of human tumors: establishment of cell lines derived from a series of solid tumors. J Natl Cancer Inst 1973; 51: 1417-1423

21 Tsao SW, Wang X, Liu Y, Cheung YC, Feng H, Zheng Z, Wong N, Yuen PW, Lo AK, Wong YC, Huang DP. Establishment of two immortalized nasopharyngeal epithelial cell lines using SV40 large T and HPV16E6/E7 viral oncogenes. Biochim Biophys Acta 2002; 1590: 150-158

22 Huang DP, Ho JH, Poon YF, Chew EC, Saw D, Lui M Li CL, Mak LS, Lai SH, Lau WH. Establishment of a cell (NPC/HK1) from a differentiated squamous carcinoma of the nasopharynx. Int J Cancer 1980; 26: 127-132 received July 29, 2015

revised November 19, 2015

accepted December 18, 2015

Bibliography

Dol http://dx.doi.org/10.1055/s-0035-1568332

Published online February 11, 2016

Planta Med Lett 2016; 3: e10-e13

(c) Georg Thieme Verlag KG Stuttgart · New York . ISSN 2199-157X

\section{Correspondence}

Khoo Teng-Jin

School of Pharmacy, Faculty of Science

Room BA35 Block B

University of Nottingham Malaysia Campus

Jalan Broga

43500 Semenyih, Selangor Darul Ehsan

Malaysia

Phone: + 6(03) 89248213

Fax: $+6(03) 89248018$

tengjin.khoo@nottingham.edu.my 